\title{
The Personal Protection from Racial Discrimination in the Conditions of Fight against Terrorism
}

\author{
Ekaterina A. Khuzina*1, Gabdrakhman H. Valiev ${ }^{2}$ \\ ${ }^{1,2}$ Kazan Federal University, Naberezhnye Chelny Institute \\ *Email: eka5551@ rambler.ru, Contact: 89631239610
}

Received: 21st October 2017 Accepted: 16th November 2017, Published: 31st December 2017

\begin{abstract}
In the context of the globalization of the economy and the integration of interstate relations, as well as the short-sighted policies of the leaders of some countries, there has appeared a serious danger of terrorist acts of various groups that have arisen on religious grounds. In such circumstances, the likelihood of racial discrimination is high. Racism needs neither explanation nor analysis. Its ineradicable slogans spread like a tide, which at any moment can flood any society. The existence of racism does not require justification. This categorical statement, as absolute as the unprovable one, means that racism has all the signs of an axiom. Accessible to all, albeit not universally accepted, racism is the more effective the more vaguely it is, and the more dynamic the more obvious it seems. The purpose of this work is to investigate the complex of criminally-legal and criminological problems of combating the incitement of national, racial or religious hatred in the conditions of terrorism. The article also proposes the scientific development of proposals and recommendations aimed at improving preventive activities, criminal legislation, as well as the practice of its application.
\end{abstract}

Keywords: International Legal Acts, Discrimination, Terrorism, Protection, Law, People.

\section{Introduction}

The Universal Declaration of Human Rights which laid the foundation of international human rights law, has enshrined that "All human beings are born free and equal in their dignity and rights" [1].

International legal acts adopted within the framework of the United Nations (hereinafter UN) impose a number of obligations on states and set before them the task of eliminating discrimination on the basis of nationality and race. However, the events taking place in the world, among which are the terrorist acts of September 11, 2001 in the United States, and a series of terrorist acts in Paris, in the Moscow metro, in the city of Volgograd, in the city of St. Petersburg, in Iran and other countries, as well as the current migration crisis in the countries of Europe, actualize the problem of race discrimination and demand its solution.

The fight against terrorism that has taken place in the States since the events of 11 September, 2001 has in some cases led to changes in legislation or regulations that are directly or indirectly discriminatory, in particular on the basis of citizenship, ethnic or religious affiliation, and even more discriminatory practice on the part of state bodies. Unfortunately, the fight against terrorism pushes back human rights norms, resulting in illegal arrests, and extradition of criminals to foreign countries, discrimination and violation of human rights. Attempts which had also being made to present some counter-terrorism strategies as consistent with these rights, while in reality they are not, also fight against human rights. All these tendencies discredit the true value of human rights.

At present, the general situation in the Russian legal system is characterized by the absence of a single terminology and a uniform approach to the formulation of legal prescriptions and prohibitions related to equality. A number of federal laws (the Criminal Code of the Russian Federation, the Code of Administrative Offenses of the Russian Federation) contain the concept of "discrimination", but all these acts use the term "discrimination" without its definition and in unequal contexts. The concept of "discrimination" also used in part 3,Article 37 of the Constitution of the Russian Federation and in Article 3 of the Labor Code of the Russian Federation, but without definition and explanation.

\section{Materials and Methods \\ This study was carried out on the basis of the general methodological provisions of the theory of knowledge; it is also based on the concept and methods of the theory of criminal law and criminal policy, sociology and psychology, criminology and general theory of law. \\ In preparing the article, such methods as analysis, synthesis, historical and legal, system-comparative, statistical, formal-logical analysis, content analysis, questioning, and interviewing were used.}

The normative base of the research was the Constitution of the Russian Federation, sources of domestic criminal law, criminal legislation of foreign countries, as well as other laws and by-laws.

The definition of racial discrimination is given in the International Convention on the Elimination of All Forms of Racial Discrimination adopted by the UN General Assembly on 21 December, 1965 and entered into force on 4 January, 1969 (Article 1, para. 1): "racial discrimination" means "any distinction, restriction or preference based on race, color, descent, 
national or ethnic origin, having the purpose or effect of destroying or impairing the recognition, use or exercise, on an equal footing, of human rights and fundamental freedoms in the political, economic, social, cultural or any other field of public life "[2].

There is also a case law of the European Court on Human Rights. The European Court found that discrimination is understood as the application of different rules in comparable situations or the application of the same rules in different situations. In support of the foregoing positions, the practice of the European Court indicates that discrimination can be open or hidden and direct or indirect [3].

The concept of discrimination has been consolidated in international acts more than half a century ago. It seems necessary to develop and consolidate in the Russian legislation the concept of discrimination which makes it possible to separate it from the concept of violation of rights and freedoms. The definition and the norms of civil and administrative law formulated on the basis of it should provide an opportunity to challenge discriminatory treatment in itself, regardless of whether it entailed a violation of rights, and without the need to prove violations of rights.

In light of the events of modern history associated with the terrorist attacks of September 11, 2001 in the United States, the UN Security Council adopted resolution No. 1373. This resolution and subsequent UN Security Council resolutions initiated large-scale actions to combat terrorism and the adoption of corresponding national laws. These normative acts are aimed at tightening border control, the movement of human and transport flows, but since it did not contain a clear definition of terrorism, states began to disregard human rights for the sake of national security in their "war on terror". To support the implementation of measures to combat terrorism, the Counter-Terrorism Committee (CTC) was established with the purpose of carrying out targeted sanctions against extremist groups and identifying cases of financing and preparation of terrorist acts.

\section{Results and Discussion}

In these circumstances, the concept of the inviolability of human rights, as well as democratic values such as pluralism, freedom and respect for the opinions of others and groups, freedom of association, and nondiscrimination, has been jeopardized.

We believe that today the key problem is the broad interpretation of terrorism, which enables national governments to abuse this concept by arbitrarily setting the limits of "ensuring national security".

The lack of a clear definition of terrorism in international law leads to serious violations of human rights, because those people may fall under the accusation of terrorism that are not only seen in the preparation of terrorist acts, but also suspected of. Moreover, in the situation of military conflicts, the principle of "rule of law" is significantly undermined by the formation of special courts over alleged terrorists.
Another problem is the ambiguous attitude towards persons considered as terrorists. So, some separatist organizations can be perceived as fighters for freedom and independence, and their actions connected with the use of violence, are justified as executed for the sake of great goals. In this context, within the framework of international law, it is necessary to consolidate the principle of preventing any acts related to the use of violence, even for the most just purposes.

Also, a significant blow shattering the very idea of international protection of human rights was the violation of the humanitarian law connected with the absolute prohibition of tortures and other forms of violence.

One of the first achievements of international human rights was the recognition of the right to freedom from torture and other torments, even during military conflicts. Beginning with The Hague Conventions of 1899 and 1907, and the Geneva Conventions of 1864 and 1949, the UN Convention against Tortures 1984, the norms of the humanitarian law prohibiting tortures are recognized as juscogens, or categorical.

Thus, torture, as well as other actions equating to them, causing physical or moral suffering to a person, cannot be justified by any circumstances, be it a war or a threat of war, since they are crimes against humanity. However, in the context of the being evolved "war on terror", states began to disregard this rule, using in courts the evidences obtained under pressure. There are new sophisticated types of torture, such as stress, isolation, deprivation of sensitivity, "simulation of drowning". Those tortures are difficult to prove because they do not leave visible traces of physical violence, but they cause no less severe suffering to the person being tortured. Evidences obtained as a result of torture are formally invalid, but in practice the judiciary takes them into account, especially in cases where it is not certain that they were obtained through tortures.

Flagrant violations of human rights are the incidences of illegal detention and arrest, as well as displacement of a person to another country, which have become more frequent in the light of anti-terrorist operations. It is well known and normatively established that any detainee has the right to know the basis of his/her detention for any reason, has the right to be assisted by a lawyer, has the right that his/her family members to be aware of the place of his/her residence, be questioned in accordance with the law, and not be transferred to the jurisdiction of another state where the person may be subjected to tortures. However, a broad interpretation of terrorism leads to the fact that persons who are absolutely uninvolved in the actions imputed to them may come under suspicion and detention.

Concern of the international community on the widespread violation of human rights led to the adoption by the UN General Assembly of the Global Counter-Terrorism Strategy [4], where it was recorded that respect for human rights does not hinder national security, but, on the contrary, is a fundamental basis in the fight against terrorism. The strategy stressed the 
need to coordinate efforts of states in the fight against terrorism, pointed out that terrorism as a phenomenon does not carry any religious, ethnic, national or civilizational interests.

\section{Summary}

Thus, terrorism is identified as a purely violent act that cannot be justified, and persons who are seen in terrorist activities cannot be granted with political asylum in the territory of other states and they are subject to a criminal court [5]. At the same time, there was a call for civil society institutions, regional and subregional organizations to coordinate their efforts to prevent terrorist attacks. In these circumstances, the mastery of the art of "bridging" between human rights and national security, both internationally and at the level of individual states, comes at the forefront in the fight against terrorism.

The importance of protection against discrimination in international human rights law cannot be overemphasized. This principle is applicable to any discrimination in conditions of detention, as well as to all other cases [6]. A different treatment that cannot be justified may constitute unlawful discrimination in matters such as collection of evidences, interrogation methods or conditions of detention. Strengthening human rights standards means that any response to an unlawful act must be strictly targeted and carefully planned in order to avoid violating human rights. Counter-terrorism measures do not have an advantage over human rights. On the contrary, in democratic societies, plans for combating terrorism must be harmonized with human rights.

Terrorist acts, and in some cases also the fight against terrorism, have also led to the spread of racist prejudice and racial discrimination on the part of individuals and organizations. [7]

It may also be noted increase in the difficulties faced by asylum-seekers in accessing asylum procedures in Council of Europe member States, and gradual weakening of the protection of refugees as a result of restrictive legislative measures and practices related to the fight against terrorism.

To date, there is an urgent need for states to promote the integration of different groups of the population as a general process that can help to prevent racism or racial discrimination, in the capacity of a public response to the atmosphere generated by the fight against terrorism.

Anti-discrimination legislation remains the main component of the system counteracting discrimination. Constitutional norms, provisions of branch laws and special anti-discrimination laws create a system of legal means to counteract discrimination, that is, its suppression and prevention.

It should be noted that anti-discrimination legislation as such is not a means of correcting social inequalities or preventing conflicts [9]. Anti-discrimination legislation should be seen as a necessary, but not sufficient condition for solving such problems and also as a first step in this direction.
At present, there is no special anti-discrimination legislation in Russia. Most of the legal norms relating to equality and discrimination are rules of substantive law, and there is clearly lack of sufficient procedural safeguards against discrimination in the law.

The question of the necessity of anti-discrimination legislation is connected with a more complex issue of its efficiency, or effectiveness. There are two ways to determine and assess this effectiveness: in terms of impact on discriminatory practices in general and in terms of the effectiveness of the means presented to the person in need of protection [10].

To date, the effectiveness criteria of antidiscrimination instruments have not been developed. To a large extent, this is due to the complexity of the task of combating discrimination and to the fact that it is inseparable from the broader agenda for social equality and overcoming spontaneous processes which lead to marginalization of certain groups of the population. However, it can be argued that anti-discrimination mechanisms make a great contribution to the unity, internal integrity and stability of many modern societies.

There are a number of terms and categories relating to equality and equal rights in the Russian Constitution and legislation. However, we can state the absence in the Russian Federation of an established categorical apparatus, that is, clear definitions and established practice of using these terms. In the legislation, there is an imbalance of substantive and procedural rules related to ensuring equal rights. In addition, the area of legal regulation relating to equality is blurred due to the existence of anti-extremist legislation [11].

In Russia, there are currently factors that both facilitate and hinder the development, adoption and application of anti-discrimination legislation. The positive factors include the following: the existence in the Constitution and legislation of substantive rules that proclaim equality of rights and prohibition of its violation; past attempts, albeit unsuccessful, introduce into legislation a definition of discrimination, decisions of the Constitutional Court on the interpretation of Article19 of the Constitution of the Russian Federation, and the recognition of the norms of international law as an integral part of the legal system of Russia.

We believe that the amount of negative factors is much larger. The social and political background in the country, which is extremely unfavorable for the adoption and implementation of anti-discrimination legislation, should be placed first. The agenda for equality and the prohibition of discrimination is replaced by other issues, and the practice of combating discrimination and discussions about equality is lacking. Professional communities have scant and distorted ideas about the experience of combating discrimination abroad.

\section{Conclusion}

Although equality of citizens' rights on racial and ethnic grounds in Russia is subject to administrative and criminal-legal protection, as already noted 
however, it is extremely difficult to prove the fact of discrimination on the basis of nationality. Judicial practice in cases related to discrimination is absent as a whole in our country. Racial discrimination did not become subject to judicial review and was not reflected in court decisions.

All of the above requires the state to pursue policies and take specific measures aimed at preventing discrimination and eliminating conditions conducive to discrimination. After all, responding to the threat of terrorism should not, in turn, undermine the values of freedom, democracy, justice, the rule of law and human rights and humanitarian law, because such efforts are aimed at protecting these values, and also that it is should not in any way undermine the protection and development of these values.

\section{Acknowledgements}

The work is carried out according to the Russian Government Program of Competitive Growth of Kazan Federal University.

\section{References}

1. Universal Declaration of Human Rights (adopted by the UN General Assembly on 10. 12. 1948) // Rossiyskaya Gazeta. - 1995. - No. 67.

2. International Convention on the Elimination of All Forms of Racial Discrimination (21 December, 1965) // Acting international law. Moscow: Publishing house of the International Independent Institute of International Law. 1997. - V. 2. - P. 72 - 84.

3. Precedents of the Grand Chamber of the European Court of Human Rights [Digital document]. - Access mode: www. commissioner. coe. int. - P. 239.

4. The United Nations Global Counter-Terrorism Strategy. URL: http://docs.cntd. ru/document/902114207.

5. Mutual praise society. Country scorecard and evaluation of the Universal Periodic Review system of the U.N. Human Rights Council // Geneva: UN Watch, 2009.

6. Ramcharan, Bertrand G. The United Nations High Commissioner for Human Rights: the challenges of international protection. The Hague; New York: Kluwer Law International, 2002.

7. Starke J.G. Human rights and international law // Human rights: ideas and ideologies. L., 1979.

8. Chowdhury, Tareq M.R. Legal Framework of International Supervision. Edsbruk, Sweden: Akademitryck, 1986. Review of annual reports under the follow-up to the ILO Declaration of fundamental Principles and rights at Work. ILO, 2008.

9. Upton, Helen. The Human Rights Council: First Impressions and Future Challenges // Human Rights Law Review. Oxford University Press, 2007.Vol. 7(1). P. 29-39.

10. Kirchmeier, Felix. The Role of Parliaments in the Universal Periodic Review: A review of resolution A/HRC/RES/5/1 of the Human Rights Council and further suggestions. Geneva: FriedrichEbertStiftung, 2009.
11. Abashidze A. Kh. , Goltyaev A. O. Universal Periodic Review // Russian Yearbook of International Law, St. Petersburg: Russia-Neva, 2011. Pp. 295-305. 